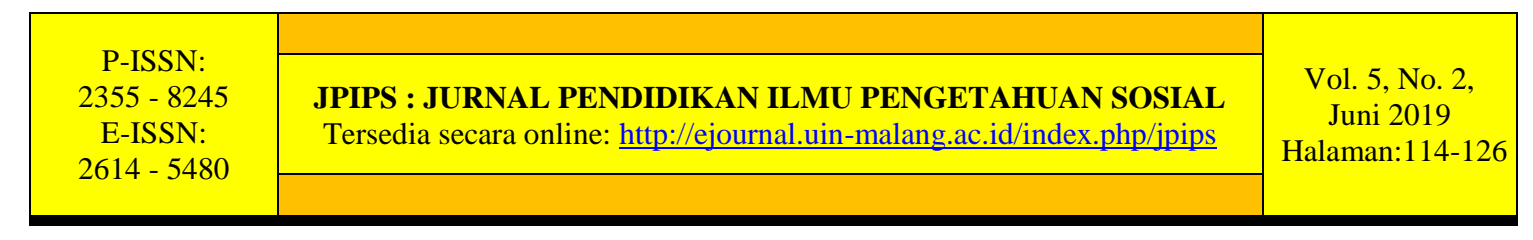

\title{
PENGEMBANGAN BUKU TEKS MITIGASI BENCANA PADA MATERI ERUPSI GUNUNG API DI SDN PENATARAN 01 KABUPATEN BLITAR
}

\author{
Ika Meviana*1, Nelya Eka Susanti*2 \\ *Universitas Kanjuruhan Malang \\ ${ }^{1}$ meviana@unikama.ac.id, ${ }^{2}$ nelyaeka@ unikama.ac.id
}

\begin{abstract}
Abstrak: Dalam mata pelajaran IPA di tingkat sekolah dasar dapat dikenalkan konsep bencana geologi, seperti mitigasi bencana yaitu bencana erupsi gunung api. Tujuan penelitian ini untuk mengetahui kelayakan isi dan penyajian materi mitigasi bencana erupsi gunung api. Selain itu tujuan pengembangan buku teks digunakan untuk mengetahui pemahaman siswa terhadap materi yang dikembangkan. Penelitian ini dirancang dengan desain pengembangan 4-D yang dimodifikasi menjadi tiga langkah, yaitu: Define, Design, Develop. Berdasarkan hasil penelitian dan pembahasan, kelayakan isi dan penyajian buku dengan materi mitigasi bencana erupsi gunung api untuk kelas $\mathrm{V}$ (lima) setelah melalui serangkaian proses validasi ahli materi, penyajian, kebahasaan, kegrafikan, uji coba terbatas, dan hasil uji coba lapangan diperoleh hasil dengan kategori sangat baik. Tingkat pemahaman siswa terhadap materi dapat dilihat dari aspek kognitif dan afektif siswa. Berdasarkan hasil kerja siswa pada lembar post test, nilai rata-rata yang diperoleh siswa yakni 82,25. Hasil tersebut menunjukkan bahwa siswa dalam belajar tentang mitigasi bencana erupsi gunung api telah tuntas. Sikap ilmiah siswa yang dominan yaitu ingin tahu, mendapatkan sesuatu yang baru dan kerjasama. Sikap ilmiah tersebut tercermin dari aktivitas siswa yang tertarik untuk mengulang-ulang percobaan dan kompak, serta dapat bekerjasama dengan baik bersama teman kelompok.
\end{abstract}

\section{Kata Kunci: Pengembangan, Buku Teks, Mitigasi Bencana, Gunung Api}

Abstract:. In science subjects at the elementary school level, the concept of geologi's disaster can be introduced, such as disaster mitigation, namely volcanic eruption disaster. The purpose of this study was to determine the contents feasibility and the book presentation of disaster mitigasion education material. In addition, the purpose of developing textbooks was to determine students' understanding of volcanic eruption disaster mitigation materials. This research was designed with a modified 4-D development design. The 4-D development design stages are Define, Design, Develop, and Disseminate. In this study the 4-D design was modified into three steps, namely: Define, Design, Develop. Based on the results of research and discussion, the feasibility of the contents and presentation of the book with Disaster Mitigation education material for grade 5 students after going through a series of processes including the validation from material experts, product presentation, language, graphics, limited trials, and field trials, the product is categorized of having very good quality. The level on students understanding of disaster mitigation education material of grade 5 books as a developed product is seen based on students cognitive and affective aspects. Based on the result of the student work on the post test sheet, the average value obtained by the students is 82,25 , 
it incates that students learning process about the mitigation of volcanic eruption disaster have been completed. The dominant scientific attitude of students are curiosity, gaining new information, and cooperation. These scientific atitudes are reflected in the activities of students who are interested in repeating the experiments and their harmonious work shown by the fact that they can work well together with friend within their group.

\section{Keywords: Development, Textbooks, Disaster Mitigation, Volcanoes}

\section{PENDAHULUAN}

Bencana erupsi gunung api merupakan fenomena yang dapat diprediksi, sehingga diperlukan usaha untuk memberikan pemahaman tentang mitigasi bencana kepada siswa, khususnya siswa tingkat sekolah dasar. Mitigasi bencana merupakan upaya pengambilan tindakan guna mengurangi risiko bahaya sebelum bahaya terjadi (Nirmalawati, dalam Suryaningsih, 2017)

Mitigasi dapat diartikan sebagai upaya atau tahapan mengambil tindakantindakan untuk mengurangi pengaruh/ resiko dari suatu bahaya sebelum bahaya tersebut terjadi (Nirmalawati, 2011). Salah satu cara yang dapat digunakan untuk memberikan pemahaman tentang mitigasi bencana erupsi gunung api dapat dilakukan melalui pembelajaran di kelas. Untuk mendukung pembelajaran tersebut dapat menggunakan buku teks yang dikembangkan.

Melalui pembelajaran dapat digunakan sebagai wadah untuk memberikan sosialisai mitigasi bencana khususnya bencana erupsi gunung api. Dimana sosialisasi tersebut dapat dilakukan melalui pembelajaran di dalam maupun luar kelas. Tujuan memberikan materi mitigasi bencana erupsi gunung api sebagai bekal atau persiapan siswa agar paham terhadap konsep mitigasi bencana, khususnya erupsi gunung api sejak dini. Selain itu agar siswa dapat membangun sikap kesiapsiagaan terhadap bencana, khususnya erupsi gunung api. Sehingga pembelajaran mitigasi bencana sejak dini yang diberikan di tingkat sekolah dasar adalah langkah awal membangun sikap tanggap bencana (Arifianti, 2011)

Usaha memberikan pemahaman materi tentang mitigasi bencana erupsi gunung api pada tingkat sekolah dasar dapat diberikan melalui substansi materi IPA. Adanya perubahan Kurikulum Tingkat Satuan Pendidikan menjadi Kurikulum 13 merupakan salah satu usaha pemerintah dalam melakukan evaluasi pelaksanaan kurikulum. Pujianto (2014) menjelaskan bahwa hasil analisis terhadap kurikulum 2013, menunjukkan beberapa kompetensi dasar pada sekolah dasar kelas tinggi yang dimungkinkan dapat digunakan dalam pembiasaan sikap siaga bencana.

Adanya perubahan kurikulum dari KTSP menjadi Kurikulum 2013 yang didalamnya ditambahkan muatan materi IPBA (Ilmu Pengetahuan Bumi dan Antariksa) merupakan wadah untuk memberikan pemahaman tentang risiko bencana. Akan tetapi K13 pada tingkat sekolah dasar belum secara penuh memberikan fasilitas edukasi tentang mitigasi bencana erupsi gunung api. Sehingga diperlukan peran aktif pendidik, dalam hal ini adalah guru. Peran aktif dan kreatif guru dapat dituangkan dalam bentuk pembelajaran menggunakan sumber belajar yaitu buku teks tentang mitigasi bencana, khususnya bencana erupsi gunung api yang sudah dikenbangkan. Dengan adanya ilustrasi fenomena bencana erupsi gunung api dapat memberikan pengetahuan dan pengalaman bagi siswa tentang mitigasi bencana.

Produk hasil pengembangan yang disisipi ilustrasi fenomena bencana dan usaha mitigasi bencana memiliki peran yang sangat penting dalam pembelajaran. SDN 
Penataran 01 belum memiliki sumber belajar tentang mitigasi bencana erupsi gunung api. Berdasarkan hasil observasi pada bulan Desember 2017, SDN Penataran 01 berada di Kawasan Rawan Bencana I, yakni kawasan yang tertimpa material jatuhan berupa hujan abu dan pasir. Berdasarkan hasil wawancara dengan Kepala Sekolah, Guru dan siswa, diperlukan memberikan materi mitigasi bencana erupsi gunung api dalam pembelajaran. Hal tersebut diperlukan karena lokasi sekolah SDN Penataran 01 berada pada Kawasan Rawan Bencana 1. Sehingga diperlukan pengembangan buku teks mitigasi bencana erupsi gunung api sebagai sumber belajar.

Menurut Prastowo (2015) buku teks merupakan buku yang berisi ilmu pengetahuan, dikembangkan berdasarkan kompetensi dasar pada kurikulum, dan digunakan oleh siswa untuk belajar. Buku teks yang dikembangkan dapat digunakan sebagai sumber belajar dalam pembelajaran. Menurut Slameto (2003), seseorang dalam hal ini adalah siswa diperlukan latihan dalam tingkah laku guna memperoleh kemajuan pola tingkah laku. Aspek kognitif, afektif serta kondisi lingkungan sekolah dipertimbangan dalam pemilihan materi dalam buku teks sebagai produk yang dikembangkan. Adanya lembar kerja siswa pada buku teks yang nantinya dikerjakan secara kerjasama dapat menciptakan sikap bekerjasama sesama siswa pada saat pembelajaran. Selain itu juga dapat membantu meningkatkan hasil belajar siswa agar lebih baik.

Berdasarkan uraian tersebut, diperlukan pengembangan buku teks sebagai sumber belajar siswa tentang materi mitigasi bencana erupsi gunung api untuk mengembangkan karakter siswa agar tanggap bencana sejak dini. Materi mitigasi bencana erupsi gunung api dipilih karena SDN Penataran 01 berada pada Kawasan rawan bencana erupsi Gunung Api Kelud.

\section{Rancangan Penelitian}

\section{METODE}

Penelitian ini dirancang dengan desain pengembangan 4-D yang dimodifikasi menjadi tiga langkah, yaitu: Define, Design, Develop. Desain ini dimodifikasi menjadi tiga langkah karena keterbatasan peneliti dalam melaksanakan langkah keempat (disseminate).

\section{Prosedur Pengembangan}

Prosedur pengembangan buku teks ini disusun dalam diagram alir. Diagram alir tersebut tergambar secara hirarki dan sistematis sesuai langkah-langkah pada tahap pengembangan sebagai berikut: 


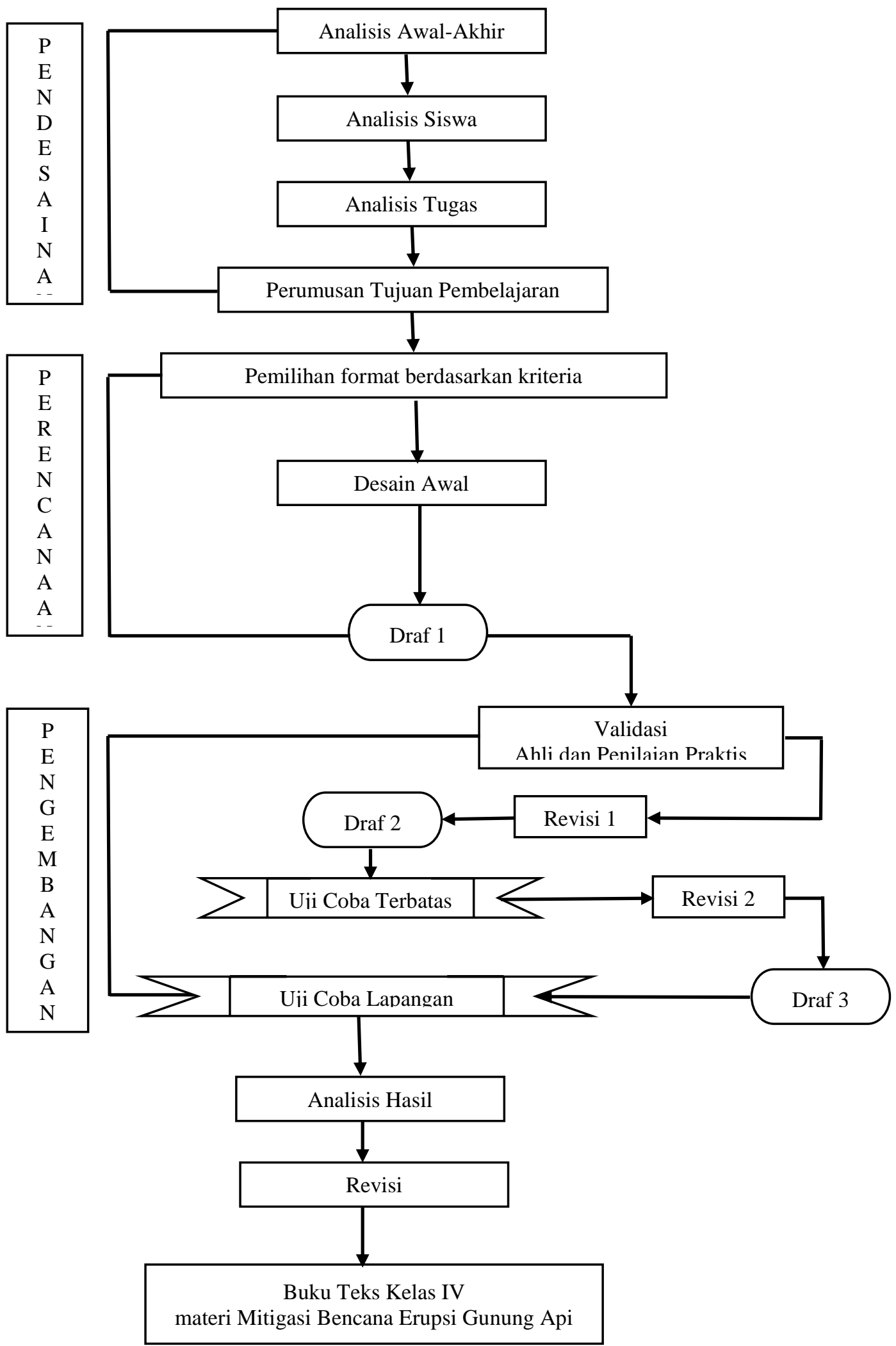

Gambar 1. Desain Produk Pengembangan yang Dimodifikasi (Thiagarajan, Sammel dan Semmel, 1974) 


\section{Uji Coba Produk}

\section{Desain uji coba}

Desain uji coba materi melalui tahapan pengembangan bahan ajar, yaitu:

a. Validasi materi/isi dilakukan oleh validator ahli materi mitigasi bencana.

b. Validasi desain pembelajaran adalah mereview kesesuaian penggunaan gambar, foto, bagan, peta pada bahan ajar oleh validator ahli desain pembelajaran.

\section{Subjek uji coba}

\section{a. Uji coba terbatas}

Uji coba terbatas dilakukan kepada tiga siswa kelas V SDN Penataran 01 Kecamatan Nglegok, yang memiliki kemampuan kognitif yaitu tinggi, sedang, dan rendah.

\section{b. Uji coba lapangan}

Uji coba lapangan dilakukan kepada 13 siswa kelas V SDN Penataran 01, Kecamatan Nglegok.

\section{Instrumen Pengumpulan Data}

1. Angket

Pilihan jawaban dalam angket menggunakan skala likert dengan empat pilihan, yaitu: sangat baik, baik, kurang baik, sangat kurang baik.

2. Tes

3. Observasi

Tes digunakan untuk mengukur aspek kognitif siswa.

Teknik observasi digunakan untuk mengetahui aspek afektif.

\section{Teknik Analisis Data}

a. Teknis Analisis Kelayakan Buku

Untuk mengetahui hasil kelayakan buku teks sebagai produk yang dikembangkan digunakan rumus sebagai berikut:

$$
\text { skor } \text { rata }- \text { rata tiap aspek }=\frac{\text { jumlah skor }}{\text { jumlah penilai }}
$$

Suharsimi Arikunto (2006)

Setelah mendapatkan skor rata-rata, selanjutnya skor tersebut dikonversi tiap masingmasing komponen aspek penilaian menjadi data kualitatif deskriptif. Untuk menentukan interval, digunakan rumus sebagai berikut:

$$
\text { jarak interval }(i)=\frac{\text { skor tertinggi }- \text { skor terendah }}{\text { jumlah kelas interval }}
$$

Widoyoko (2014) 
Tabel 1. Konversi Skor Penilaian masing-masing Komponen Aspek Materi, Penyajian, Kebahasaan dan Kegrafikan

\begin{tabular}{cccc}
\hline Komponen Aspek Materi & Interval Skor & Nilai & Kategori \\
\hline \multirow{3}{*}{ Kelayakan Isi } & $3,25 \leq \mathrm{X} \leq 4,00$ & $\mathrm{~A}$ & Sangat Baik \\
& $2,50 \leq \mathrm{X}<3,25$ & $\mathrm{~B}$ & Baik \\
& $1,75 \leq \mathrm{X}<2,50$ & $\mathrm{C}$ & Kurang \\
& $1,00 \leq \mathrm{X}<1,75$ & $\mathrm{D}$ & Sangat Kurang \\
Penyajian & $3,25 \leq \mathrm{X} \leq 4,00$ & $\mathrm{~A}$ & Sangat Baik \\
& $2,50 \leq \mathrm{X}<3,25$ & $\mathrm{~B}$ & Baik \\
& $1,75 \leq \mathrm{X}<2,50$ & $\mathrm{C}$ & Kurang \\
& $1,00 \leq \mathrm{X}<1,75$ & $\mathrm{D}$ & Sangat Kurang \\
Kebahasaaan & $3,25 \leq \mathrm{X} \leq 4,00$ & $\mathrm{~A}$ & Sangat Baik \\
& $2,50 \leq \mathrm{X}<3,25$ & $\mathrm{~B}$ & Baik \\
& $1,75 \leq \mathrm{X}<2,50$ & $\mathrm{C}$ & Kurang \\
& $1,00 \leq \mathrm{X}<1,75$ & $\mathrm{D}$ & Sangat Kurang \\
Kegrafikan & $3,25 \leq \mathrm{X} \leq 4,00$ & $\mathrm{~A}$ & Sangat Baik \\
& $2,50 \leq \mathrm{X}<3,25$ & $\mathrm{~B}$ & Baik \\
& $1,75 \leq \mathrm{X}<2,50$ & $\mathrm{C}$ & Kurang \\
& $1,00 \leq \mathrm{X}<1,75$ & $\mathrm{D}$ & Sangat Kurang \\
\hline
\end{tabular}

b. Teknik Analisis Pemahaman Siswa

1. Aspek kognitif

Penilaian aspek kognitif dilaksanakan melalui post-test.

2. Aspek Afektif

Analisis data yang digunakan yaitu deskriptif kualitatif untuk menjelaskan hasil pengamatan aspek afektif.

\section{Kelayakan Isi dan Penyajian Buku}

\section{HASIL DAN PEMBAHASAN}

Hasil

a. Deskripsi Hasil Tahap Pendefinisian (Define)

Pada tahapan ini dibagi menjadi lima tahapan sebagai berikut:

1) Analisis Awal-Akhir

Hasil observasi awal menunjukkan SDN Penataran 01 Kecamatan Nglegok, Kabupaten Blitar berada pada Kawasan Rawan Bencana I. Sekolah ini belum memiliki bahan ajar sebagai sumber belajar tentang materi mitigasi bencana erupsi gunung api.

2) Analisis Siswa

Analisis ini dilakukan guna mengetahui karakteristik siswa. Setelah dilakukan analisis terhadap siswa kelas V SDN Penataran 01, diketahui bahwa siswa kelas V memiliki variasi tingkat pengetahuan dan keterampilan terhadap kesiapsiagaan bencana khususnya erupsi gunung api.

3) Analisis Konsep

Dalam buku teks yang dikembangkan, disajikan konsep sebagai berikut: 


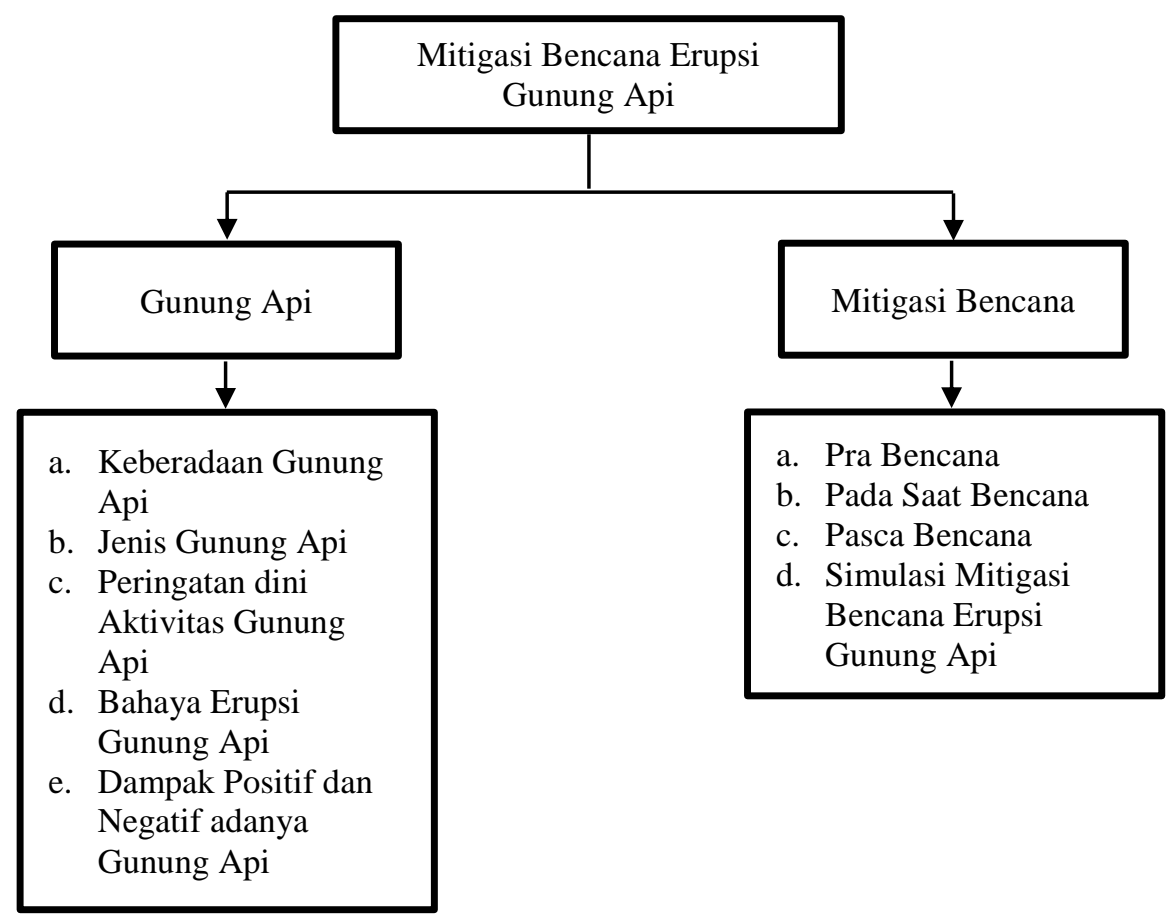

4) Analisis Tugas

Tugas terdiri dari: Lembar Kerja Siswa (LKS), mendemonstrasikan terjadinya erupsi gunung api, melaksanakan simulasi mitigasi bencana erupsi gunung api dan megerjakan soal evaluasi.

b. Deskripsi Hasil Tahap Perencanaan (Design)

1) Pemilihan Format Berdasarkan Kriteria

a) Materi

Pembahasan berkaitan dengan gunung api tidak terepas dari kondisi lingkungan alam dan letak gunung api yang dekat dengan tempat tinggal siswa.

b) Penyajian Materi

Salah satu aspek yang perlu diperhatikan guna memperoleh kualitas yang baik untuk pengembangan buku teks adalah penyajian materi, meliputi: teknik, pendukung, dan urutan penyajian materi.

c) Kebahasaan

Fokus dari aspek kebahasaan yaitu lugas, komunikatif, dan sesuai dengan kaidah Bahasa Indonesia.

d) Kegrafikan

Aspek kegrafikan ini dibagi menjadi: ukuran buku, desain cover buku, dan desain isi buku. Buku ini dicetak ukuran kertas A4.

2) Desain Awal Produk

Proses penyusunan buku teks menggunakan aplikasi Coreldraw. Penyusunan buku teks ini meliputi: materi, penyajian materi, kebahasaan, dan kegrafikan.

\section{c. Deskripsi Hasil Tahap Pengembangan (Develop)}

Tahap Develop yaitu: validasi ahli (materi, penyajian materi, kebahasaan dan kegrafikan), uji coba terbatas dan lapangan. Hasil validasi oleh validator digunakan sebagai dasar kelayakan buku teks yang dikembangkan. 
1) Data Validasi Ahli Materi, Penyajian, dan Kebahasaan

Proses validasi ini dilakukan oleh Dwi Kurniawati, M. Pd yang terdiri dari beberapa tahapan penilaian. Proses validasi dilakukan dua kali. Validasi pertama dilaksanakan pada tanggal 23 November 2018 dan validasi kedua dilaksanakan pada tanggal 10 Desember 2018.

Hasil penilaian dari validator tahap satu memperoleh skor total 115 dengan rata-rata 3,03. Berdasarkan pedoman konversi maka produk buku hasil pengembangan termasuk dalam kategori baik. Setelah selesai revisi tahap pertama, dilakukan validasi tahap kedua. Berdasarkan penilaian validator, diperoleh skor total 127 dengan rata-rata 3,34. Sehingga dapat dikayakan produk hasil pengembangan termasuk dalam kategori sangat baik. Saran yang diberikan oleh validator pada validasi tahap dua yaitu:

a. Perlu konsistensi penulisan rujukan atau sumber pada teks dan gambar.

b. Umpan balik sebaiknya lebih ditekankan kepada siswa.

Berikut disajikan rangkuman hasil validasi oleh validator pada masing-masing aspek.

Tabel 2. Rangkuman Hasil Validasi Ahli Materi, Penyajian, dan Kebahasaan Tahap 1 dan 2 pada masing-masing Komponen

\begin{tabular}{ccccccc}
\hline Tahap & \multicolumn{6}{c}{ Rata-rata Skor dan Kategori } \\
\cline { 2 - 7 } & $\begin{array}{c}\text { Komponen } \\
\text { Aspek } \\
\text { Materi }\end{array}$ & Kategori & $\begin{array}{c}\text { Komponen } \\
\text { Aspek } \\
\text { Penyajian }\end{array}$ & Kategori & $\begin{array}{c}\text { Komponen } \\
\text { Aspek } \\
\text { Kebahasaan }\end{array}$ & Kategori \\
\hline I & 3 & Baik & 3,12 & Baik & 2,83 & Baik \\
II & 3,33 & Sangat Baik & 3,35 & Sangat Baik & 3,33 & Sangat Baik \\
\hline Sumber: Hasil Analisis, 2019 & & & &
\end{tabular}

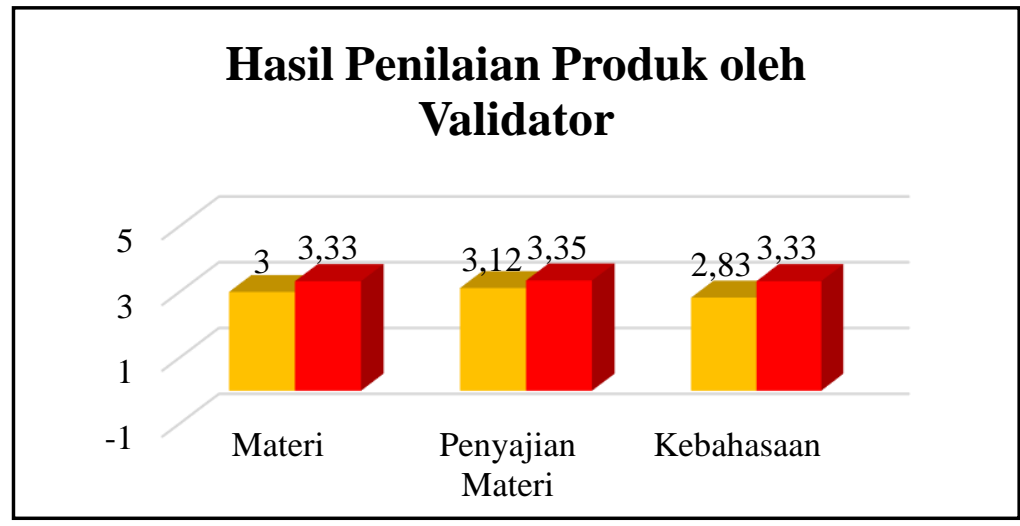

Gambar 2. Grafik Hasil Penilaian Aspek Materi, Penyajian dan Kebahasaan oleh Validator

Sumber: Hasil Pengolahan Data, 2019

2) Data Validasi Ahli Kegrafikan

Ahli kegrafikan dalam pengembangan produk ini adalah Suwito, M. Pd. Validasi yang dilakukan oleh validator ahli kegrafikan terdiri dari beberapa komponen, yaitu: ukuran buku, desain kulit buku, dan desain isi buku. Validasi pada aspek kegrafikan dilakukan dua tahap. Tahap yang pertama dilaksanakan pada tanggal 20 Desember 2018 dan validasi kedua dilaksanakan pada tanggal 1 Januari 2019. Hasil validasi tahap pertama diperoleh skor 111 dengan rata-rata 3,17, sehingga masuk dalam kategori baik. Tahap kedua, setelah dilakukan validasi oleh validator ahli kegrafikan diperoleh total skor 123 dengan nilai rata-rata 3,51 sehingga dapat dikategorikan sangat 
baik. Saran yang diberikan oleh validator pada hasil validasi tahap kedua yakni, memperbaiki bentuk ilustrasi disesuaikan dengan kenyataan. Berikut disajikan rangkuman hasil validasi oleh validator pada masing-masing aspek.

Tabel 3. Rangkuman Hasil Validasi Kegrafikan Tahap 1 dan 2 pada masing-masing Komponen

\begin{tabular}{ccccccc}
\hline Tahap & \multicolumn{6}{c}{ Rata-rata Skor dan Kategori } \\
\cline { 2 - 7 } & $\begin{array}{c}\text { Komponen } \\
\text { Ukuran } \\
\text { Buku }\end{array}$ & Kategori & $\begin{array}{c}\text { Komponen } \\
\text { Desain } \\
\text { Kulit } \\
\text { Buku }\end{array}$ & Kategori & $\begin{array}{c}\text { Komponen } \\
\text { Desain Isi } \\
\text { Buku }\end{array}$ & Kategori \\
\hline I & 2 & Kurang & 3 & Baik & 3,36 & Sangat Baik \\
II & 3,5 & Sangat Baik & 3,55 & Sangat Baik & 3,68 & Sangat Baik \\
\hline
\end{tabular}

Sumber: Hasil Analisis, 2019

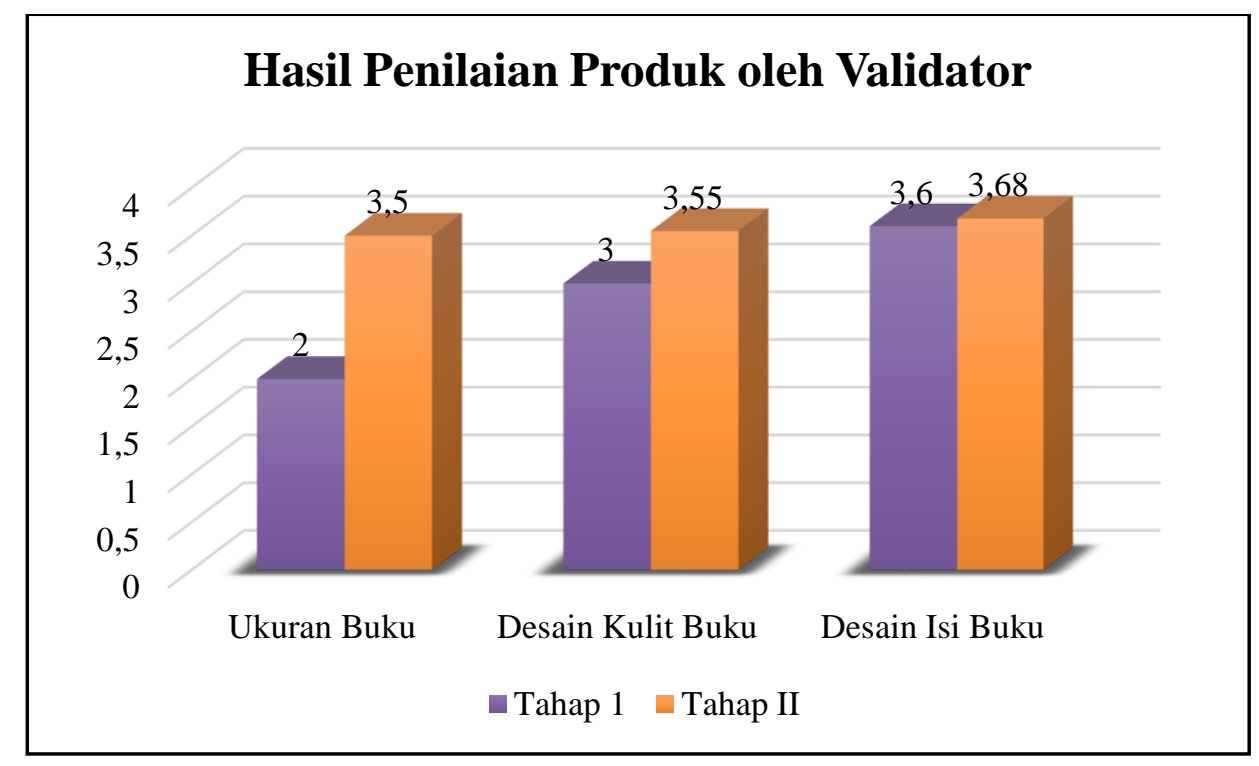

Gambar 3. Grafik Hasil Penilaian Aspek Kegrafikan oleh Validator Sumber: Hasil Pengolahan Data, 2019

Berdasarkan grafik pada gambar 3 maka dapat diketahui bahwa validasi yang dilakukan selama dua tahap memperlihatkan kenaikan perolehan skor. Validasi oleh validator dilakukan sebanyak dua kali sehingga menghasilkan produk yang layak untuk diujicobakan pada siswa kelas V di SDN Penataran 01 Kecamatan Nglegok. Hal tersebut sesuai dengan pendapat Akker (dalam Sofnidar \& Sabil, 2012) yang menyatakan bahwa kualitas perangkat pembelajaran setidaknya dilihat dari kriteria kevalidan, kepraktisan, dan keefektifan.

3) Data Hasil Uji Coba Terbatas

Tanggal 15 Januari 2019 dilakukan uji coba terbatas pada tiga siswa kelas V SDN Penataran 01 dengan tingkat kemampuan rendah, sedang dan tinggi. Subyek uji coba mengikuti pembelajaran selama $2 \times 35$ menit dengan menggunakan produk yang sudah dikembangkan. Setelah mengikuti pembelajaran subyek uji coba diberikan angket untuk menilai produk yang sudah dikembangkan oleh peneliti. Hasil uji coba terbatas menunjukkan jumlah skor total yaitu 205 dengan skor rata-rata 3,42. Berdasarkan 
pedoman konversi maka produk hasil pengembangan dapat dikategorikan sangat baik. Pada saat dilakukan uji coba terbatas, subjek penelitian terlihat antusias dalam pembelajaran menggunakan produk yang dikembangkan.

4) Data Hasil Coba Lapangan

Tanggal 22 Januari dilakukan uji coba lapangan kepada siswa yang berjumlah 12 siswa kelas V SDN Penataran 0. Subjek penelitian mengikuti pembelajaran dengan menggunakan produk hasil pengembangan selama 2 × 35 menit. Setelah pembelajaran selesai, subjek uji coba diberi angket untuk memberikan penilaian terhadap produk hasi pengembangan.

d. Revisi Produk

Tahapan ini merupakan langkah untuk merevisi produk berdasarkan prosedur penelitian yang sudah dirancang. Revisi produk meliputi dua tahapan. Tahap pertama produk direvisi berdasarkan masukan dan saran dari validator. Validator yang digunakan meliputi validasi materi, penyajian materi, kebahasaan dan kegrafikan. Tahap revisi kedua dilakukan setelah uji coba lapangan. Masukan dan saran selama uji coba yang diperoleh dari siswa digunakan untuk merevisi produk agar sesuai kebutuhan di lapangan.

Revisi produk pertama dilaksanakan setelah produk selesai disusun dan dicetak menjadi teks ajar mitigasi bencana erupsi gunung api. Bahan ajar hasil revisi berupa buku teks mitigasi bencana erupsi gunung api. Masukan, saran, dan penilaian dari validator sangat bermanfaat untuk merevisi produk pengembangan. Hasil validasi tersebut mengarahkan pada perbaikan dari aspek materi, data/fakta, dan tanda baca. Sedangkan dari ahli kegrafikan, hasil validasi mengarahkan pada perbaikan tata letak ilustrasi, dan perbaikan daftar rujukan. Hasil revisi dari penilaian validator ahli materi, penyajian materi, kebahasaan dan ahli kegrafikan dijadikan dasar dalam tahapan uji coba.

\section{Tingkat Pemahaman Siswa terhadap Materi Mitigasi Erupsi Gunung Api}

Sebagai tolok ukur mengetahui tingkat pemahaman materi, maka dapat dilihat dari aspek kognitif siswa. Aspek kognitif dapat dilihat dari hasil siswa mengerjakan soal latihan. Berdasarkan hasil kerja siswa pada lembar post tes, maka nilai rata-rata siswa 82,25. Hal tersebut membuktikan ketuntasan belajar siswa.

Selain aspek kognitif, aspek afektif juga dapat dijadikan sebagai tolok ukur mengukur pemahaman siswa terhadap materi. Aspek afektif ini dapat diamati selama pembelajaran berlangsung. Aspek afektif disesuaikan dengan sikap ilmiah dalam pembelajaran yang meliputi: ingin tahu, ingin mendapatkan sesuatu yang baru, tidak putus asa, tanggung jawab, mawas diri, kerjasama, kedisiplinan, dan berpikir bebas.

Berdasarkan pengukuran aspek afektif, maka terlihat sikap ingin tahu siswa yang tinggi sebagai sikap ilmiah yang dominan muncul, mendapatkan sesuatu yang baru dan kerjasama. Sikap ilmiah tersebut tercermin dari siswa yang mengulang-ulang percobaan dan kompak serta dapat bekerjasama dengan baik bersama teman kelompok. Gambar 4.3 berikut menunjukkan kegiatan siswa dalam melaksanakan percobaan yang menunjukkan sikap ingin tahu dan dapat bekerjasama dengan teman kelompok. 


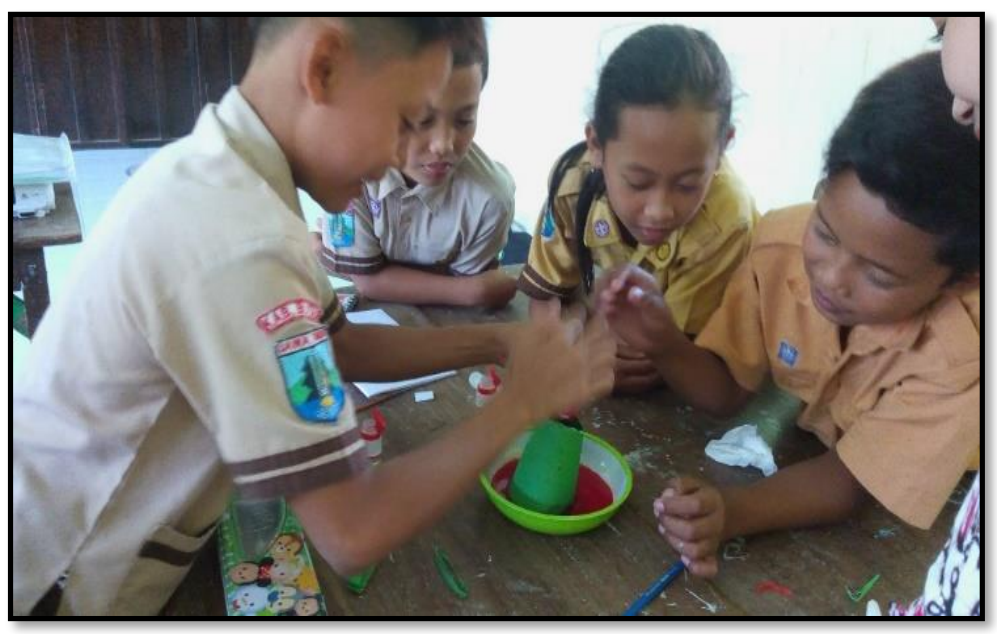

Gambar 4. Kegiatan Siswa dalam Melakukan Percobaan

\section{Pembahasan}

\section{Kelayakan Isi dan Penyajian Buku Materi Mitigasi Bencana untuk Kelas V (Lima) sebagai Produk yang dikembangkan}

Berdasarkan hasil observasi dan permasalahan yang ditemukan dari hasil wawancara, maka perlu dikembangkan buku teks mitigasi bencana erupsi gunung api sebagai salah satu suumber belajar siswa. Buku teks tersebut perlu dikembangkan karena lokasi SDN Penataran 01 berada pada Kawasan rawan bencana erupsi gunung api Kelud. Dengan dikembangkannya buku teks tersebut dapat digunakan sebagai salah satu sumber belajar siswa. Buku teks dikembangkan dengan desain pengembangan 4-D yang dimodifikasi menjadi tiga langkah, yaitu: Define, Design, Develop.

Materi mitigasi bencana yang terdapat dalam buku teks yang telah dikembangkan dapat menambah pengetahuan dan melatik sikap sigap terhadap bencana sejak dini. Selain itu dengan dikembangkannya buku teks dapat mengenalkan karakteristik kondisi lingkungan sekitar tempat tinggal siswa. Hal tersebut dibuktikan dengan kesesuain materi dengan karakteristik mata pelajaran, dimana diperoleh skor rata-rata 3,33 dengan kategori sangat baik.

Penyajian materi tentang mitigasi bencana erupsi gunung api dimuali dengan keberadaan, jenis, peringatan dini, bahaya erupsi, keuntungan dan kerugian adanya gunung api. Sedangkan pada materi mitigasi bencana erupsi gunung api dipaparkan materi tentang pra bencana,pada saat bencana, dan pasca bencana.

Urutan penyajian materi pada buku teks yang sudah dikembangkan memperoleh skor 3,20 yang dikategorikan baik. Dengan pemaparan materi yang runtut, maka siswa akan lebih mudah mempelajari materi. Selain penyajian materi yang runtut, materi yang lengkap dalam pengembangan buku teks ini juga dapat memberi kemudahan siswa mempelajari materi. Penyajian kelengkapan materi mendapat skor rata-rata sebesar 3,27 dengan kategori sangat baik. Hal tersebut dapat diartikan bahwa materi yang terdapat dalam buku teks dapat dijadikan sebagai ssalah satu sumber belajar bagi siswa khususnya dalam mempelajari tentang mitigasi bencana erupsi gunung api.

\section{Tingkat Pemahaman Siswa terhadap Materi Mitigasi Bencana pada Buku kelas V (Lima) sebagai Produk yang dikembangkan}

Tingkat pemahaman siswa terhadap materi dilihat dari hasil kerja siswa mengerjakan LKS dan mengerjakan soal post test. Pemahaman siswa terhadapa materi 
dapat diamati dari keterampilan siswa. Keterampilan siswa dapat dilihat dari keaktifan siswa dalam pembelajaran, rasa ingin tahu siswa untuk mengerjakan LKS dan semangat siswa dalam mengikuti simulasi mitigasi bencana erupsi gunung api.

Rasa ingin tahu siswa merupakan sikap ilmiah yang bisa dikembangkan. Hal tersebut terlihat saat siswa secara berulang-ulang melakukan percobaan erupsi gunung api. hal tersebut membuktikan bahawa siswa memiliki rasa ingin tahu yang tinggi. Pernyataan tersebut sesuai dengan pendapat Izzaty (2008) yang menyatakan bahwa siswa usia kelas tinggi memiliki ciri-ciri rasa ingin tahu, ingin belajar dan realistisnya tinggi. Percobaan erupsi gunung api dilakukan untuk mengetahui proses yang terjadi ketika gunung api mengalami erupsi.

Seluruh siswa kelas $\mathrm{V}$ dengan sangat antusias mengikuti simulasi mitigasi bencana. Dalam kegiatan simulasi dapat terlihat ketrampilan siswa merancang, melakukan percobaan dan keterampilan menerapkan. Hal tersebut terlihat dari kemampuan siswa dalam menerjemahkan petunjuk dari peneliti yang bertindak sebagai guru. Pelaksanaan simulasi juga didukung dengan halaman sekolah yang luas. Dimilikinya halaman yang luas digunakan sebagai tempat titik kumpul. Rambu-rambu evakuasi dipasangkan pada dinding kelas. Antusiasme dan keterampilan siswa dapat menunjukkan sejauh mana siswa dapat memahami materi yang sudah diberikan sebelumnya.

Tingkat pemahaman siswa terhadap materi dilihat dari kemampuan kognitif siswa. Pada akhir pembelajaran, siswa diberi postes untuk mengetahui tingkat pemahaman terhadap materi. Berdasarkan hasil penelitian, diperoleh skor rata-rata siswa sebesar 82,25 . Hal tersebut membuktikan bahwa siswa memahami materi tentang mitigasi bencana erupsi gunung api.

\section{KESIMPULAN}

1. Kelayakan isi dan penyajian buku teks hasil pengembangan setelah divalidasi oleh validator ahli materi, penyajian, kebahasaan, kegrafikan, uji coba terbatas dan lapangan tergolong dalam kategori sangat baik.

2. Pemahaman siswa terhadap materi pada produk yang dikembangkan terlihat dari aspek kognitif dan afektif siswa, yakni aspek kognitif dapat dilihat dari hasil post tes siswa. Berdasarkan hasil kerja siswa pada lembar post test, diperoleh nilai rata-rata 82,25, yang artinya siswa telah tuntas dalam pembelajaran. Aspek afektif dapat diamati selama pembelajaran berlangsung. Sikap ilmiah tercermin dari siswa yang mengulang-ulang percobaan dan kompak serta dapat bekerjasama dengan baik bersama teman kelompok. Sikap yang muncul yaitu sikap ingin tahu, mendapatkan sesuatu yang baru dan kerjasama..

\section{UCAPAN TERIMA KASIH}

Penulisan penelitian ini tidak lepas dari bantuan berbagai pihak secara langsung maupun tidak langsung. Oleh karena itu diucapkan terima kasih kepada:

1. Rektor Universitas Kanjuruhan Malang beserta jajarannya atas dukungan dan motivasi dari Lembaga dan kemudahan proses pelaksanaan penelitian ini.

2. Ketua LPPM Universitas Kanjuruhan Malang beserta jajarannya yang telah membantu dalam proses monitoring maupun pelaksanaan penelitian ini.

3. Dekan Fakultas Ilmu Pendidikan Universitas Kanjuruhan Malang atas segala kemudahan yang diberikan. 
4. Kaprodi Pendidikan Geografi yang telah memberikan motivasi dalam penyelesaian penelitian ini.

5. Budi Santoso, S. Pd selaku Kepala Sekolah SDN Penataran 01 yang telah memberikan ijin dalam melaksanakan penelitian.

\section{DAFTAR PUSTAKA}

Arifianti, Y. (2011). Buku Mengenal Tanah Longsor Sebagai Media Pembelajaran Bencana Sejak Dini. Bulletin Vulkanologi dan Bencana Geologi,6(3), 17-24

Izzaty, Rita Eka. (2008). Perkembangan Peserta Didik. Yogyakarta: UNY Press

Prastowo, A. (2015). Panduan Kreatif Membuat Buku teks Inovatif. Jogjakarta: Diva Press

Pujianto. (2014). Analisis Kontribusi KTSP dan Kurikulum 2013 di Sekolah Dasar Dalam Pendidikan Mitigasi Bencana Gunung Api. Prosiding, Seminar Nasional. Yogyakarta: FMIPA UNY.

Semmel, Thiagarajan D.S., \& Semmel. 1974. Instructional Development for Training Teacher of Exceptional Children a Sourcebook. Bloomington: Center for innovation on Teaching the Handicaped

Sofnidar, \& Sabil, H. (2012). Pengembangan Bahan Ajar Pendidikan Matematika I dengan Pendekatan Kontekstual. Jurnal Pendidikan Matematika. (Online) Diambil dari: http://online-journal.unja.ac.id.

Suryaningsih, Eni dan Laila Fatmawati. (2017). Pengembangan Buku Cerita Bergambar tentang Mitigasi Bencana Erupsi Gunung Api untuk Siswa SD. Jurnal Profesi Pendidikan Dasar. (Online) Diambil dari: http://journals.ums.ac.id/index.php/ppd/article/view/5310/3621. 